\title{
Sociology of Max Weber in the 21st Century: From Reception to Actualization *
}

\author{
Alexander F. Filippov \\ Doctor of Sociological Sciences, Professor, Head of the Centre for Fundamental Sociology, \\ National Research University - Higher School of Economics \\ Address: Myasnitskaya Str., 20, Moscow, Russian Federation 101000 \\ E-mail: filippovaf@gmail.com \\ Nail Farkhatdinov \\ Senior Research Fellow, Centre for Fundamental Sociology, \\ National Research University - Higher School of Economics \\ Address: Myasnitskaya Str., 20, Moscow, Russian Federation 101000 \\ E-mail: nfarkhatdinov@hse.ru
}

This issue of the Russian Sociological Review is dedicated to Max Weber. It could be called an anniversary issue since one of Weber's famous works will celebrate its centenary immediately after the Review's publication. At the end of January, 1919, Weber delivered his famous speech Politik als Beruf (Politics as a Vocation), which was published in July of the same year. This is a remarkable coincidence, but still, no more than just a coincidence. In the many contributions to our issue (though not in all of them), Weber appears first as a political thinker and a political figure; meanwhile, we did not plan to celebrate the anniversary of any of his writings (yet some anniversary dates were indicated in the circulated call for papers). Scientists all over the world are reacting to this date and will continue to react to further dates. However, we should admit that these are the external causes to remember Weber and to return to his ideas. The social convention of encouraging the celebration of anniversaries marked by good round figures also holds in science. Weber's contemporary and great friend, Georg Simmel, would say that we are dealing with the aesthetics of numbers here, ${ }^{1}$ which is more formal than a substantial approach. If there

(C) Alexander F. Filippov, 2019

(C) Nail Farkhatdinov, 2019

(c) Centre for Fundamental Sociology, 2019

DOI: $10.17323 / 1728-192 X-2019-2-9-15$

* The results of the project "Between Political Theology and Expressive Symbolism: The Discursive Formations of the Late Modernity as a Challenge to the Social Order" carried out within the framework of the Basic Research Program at the National Research University Higher School of Economics (HSE) in 2019, are presented in this work.

В данной работе использованы результаты проекта «Между политической теологией и экспрессивным символизмом: дискурсивные формации позднего модерна как вызов социальному порядку», выполняемого в рамках Программы фундаментальных исследований НИУ ВШЭ в 2019 году.

1. Although Simmel discussed only groupings of people, we can extend his ideas to other operations with numbers in the social life. Cf.: "Whether the division into numerically equal subgroups is rough and in practice continually modified ... in either case it betrays most clearly and pitilessly the existence for its own sake of the law of formation for the group, in one case as a newly emerging tendency which is in perpetual conflict and compromise with other tendencies, in another case an absolutely thoroughgoing application" (1902: 28). 
is a necessity to return to Weber, then, in fact, it does not matter whether it is the 99th or the 113th anniversary. However, although sociologists themselves are aware of the conventional nature of such conventions better than others, they are not inclined to violate the established rituals once again. We are really in the middle of our journey and still far from completing the series of Weberian anniversaries. In addition to the opportunity to remember him in the year of the anniversary of his death, we certainly will not miss the centenary of the first posthumous editions of his works, whether it be the first volume of Gesammelte Aufsätze zur Religionssoziologie (1920), or Grundriss der Sozialökonomik (1922). Yet, there is a question that is much more important, because anniversaries are celebrated only when there is no doubt in their subject.

To what extent does Weber indeed remain relevant today, while remaining a classic and while meaning more to living science than being a mere source for its self-identification? There is no doubt that Weber still retains his significance for sociology, since his recognition as an undisputed classic preserves the unity of discipline to some extent. However, does this mean that he remains an indispensable source in the practice of sociological research? On the one hand, it would be strange for sociologists to look for new reasons to deal with Weber at all. On the other hand, Weber's being taken for granted as a classic does not consistently remain the same. The recent times of the quiet confidence in the self-evident right of classics to attract our attention have passed. Our times have changed, and now we are not so confident to repeat that Weber remains "a source of endless fascination" (Adair-Toteff, 2014). Even the intense attempts of a few decades ago to question the status of the classics have ceased to play a significant role in recent discussions. Ambitious projects somehow related to what Jeffrey Alexander once called "the centrality of the classics" (1987) continue to evolve without the explicit, persistent application of their classical concepts to modernity. ${ }^{2}$ In 2001, in the Introduction to the first issue of the Journal of Classical Sociology, we read that

We take the view that in recent years the preference for "social theory" has in fact diluted the intellectual vitality and force of "sociological theory." One might take the charitable view that "social theory" is simply parallel to "political theory" ... The promotion of social theory has often been a publishing strategy to situate theory books in a larger and more effective market strategy. However, this strategy may have little intellectual value for sociology. Social theory becomes a ragbag for almost any set of observations on modern society. There is no sense of an effective distinction between opinion and theory. (Turner, O’Neill, 2001: 9, 10)

2. A good example is the work of Richard Münch. His book Theorie des Handelns (1982) begins with the assertion that the classics of sociology must be treated with the same philological precision as the classics of philosophy. It was the spirit of the age. However, only a few years later, he published the English translation of selected chapters of this title (Münch, 2011 [1988]). Münch called it 'the next step' in comparison to an earlier book, and declared the development of the theory of modern society through the framework of classical sociology. Now, thirty years later, we could ask, "Who else is ready to deal with voluntaristic theory of action?" The author's latest publications (2016) show only a very limited use of Weber, as is the case with other classics. 
We can interpret this diagnosis as a strong assertion. Sociology, it is said, is being decomposed into fragmented pieces. Although this has a negative impact on a discipline, we can overcome this state by turning to the ways in which sociological theory is produced. The word "fragmentation" may have turned out to be a very successful word in this essential text. One who is familiar with computers and the peculiarities of harddrive disks will inevitably recall that the problems of fragmentation of a hard-drive can be solved by its defragmentation; after that, the system is expected to work much faster. However, the defragmentation of sociology has failed since it has not been possible to distinguish it from social theory and political philosophy. On the contrary, it is not the market considerations but rather the substantially scientific ones that are responsible for the increasing penetration of social (but not sociological!) theory and political philosophy into the field where sociology seemed to feel more confident. Today, it appears as much more fragmented, less efficient, and sometimes as more archaic than a science should be in the 21st century.

Probably, in this context, the return to the classics, first of all, to Weber and Durkheim, has a different meaning than a quarter of a century ago. It is not about showing the world the best of sociology, nor is it about simply using authoritative sources in the routine of current research. However pretentious it may sound, the point is to try to save sociology as a big project, a project, that despite its considerable background, emerged being exactly formulated in a very specific period of history, and a project that owes its greatest success to the astonishing results of a small circle of intellectuals including Max Weber.

There are some simple objections to the classics of sociology which seem to be difficult to refute, and are in line with the ideas about science which they implicitly assume. In general, they come down to the fact that social life is too fast-changing and that, over time, one certainly can go on having respect for the founding fathers of sociology but not benefit from their results. Even if science cannot offer anything better in terms of the quality of research, it still faces a completely different object of this research. Classical sociology has become obsolete not because science has moved forward, but because its object has changed. ${ }^{3}$ There may be lengthy discussions here, but they are unlikely to work if we consider that science only deals with eternal objects to which it is becoming increasingly closer in the process of its evolution. Although this approach is incorrect in general, there is something very important and absolutely correct about it. Indeed, too much has changed since the creation of classical sociology. There emerged something that did not exist, but that which had existed has disappeared. Is it enough to state this fact to agree with such criticism, at least partially? It seems to us that this is not the case.

The historical context is not only changing, but sometimes the realities that seem to have faded away have come back. It happens so that we have to speak again about what was considered to be gone forever, and then, perhaps, not the historical diagnoses posed by the classics but the historical conditions of classical-concepts production become relevant. The State is the first to come to the mind among the issues which return. Since

3. This is the argument against sociology made, for example, in the context of phronetic social science (Flyvbjerg, 2001: Part One). 
the 1990s, globalization seems to be the main distinctive feature of our age. The states' and territorial divisions inherited from the post-war era were gradually receding into the background. Meanwhile, the State was among the key insights of classical sociology. In the last years of his life, Weber considered the state to be one of the most important political formations, using the term Verband (an organization, as it would be interpreted even in the new translation of Weber's work: 2019: 128ff., 135ff.). It is Verband, according to Weber, that establishes the main patterns of human behavior within a given territory. The world is divided among states, and there are no unions which are more powerful over them, no cultural and social norms or norms of international law that have a universal significance for all states. Political Verband is therefore the ultimate reality for itself and for those living on the territories it can invade and occupy. We do not have the intention to portray Weber as a determined imperialist. We are only talking about what he thought was obvious when he was drafting the first chapter of Economy and Society, known to us as the Soziologische Grundbegriffe, at the close of his days after the end of the Great War. The last two notions that Weber talked about in this chapter were Herrschaftsverband (the ruling organization, according to the quite-misleading interpretation) and hierokratischer Verband (hierocratic organization). These are institutions that can coerce their members either through the legitimate use of physical force, or through their promise of salvation as a reward for good behavior. These are the most important rivals in the field of basic motivation; this is exactly what Weber himself saw, and this is what his readers saw.

The current return of the state, the return of its role, and the reduction of the role of international law and, possibly, of international organizations allows us to read Weber not in a new way, but anew, that is, as the one who had had a social experience which, in part, was similar to our own. In the same way, we now newly understand the role of hierocratic alliances vying with each other for huge salvation markets. After decades of secularization, the leading religious motivation as found by Weber begins to play an increasingly important role in economic and political life as well.

This is why we read Weber's thoughts on the possibilities and prospects of modernity. It is not on the need to complement political procedures with some charismatic leadership, and not as some scholarly truth, but as an old question stated anew. Perhaps the most important thing here is not so much an impressive return into politics or other spheres of social life of those elements that remind us in the most definite way of Europe after the First World War, but rather the return of that specific uncertainty or diversity of possibilities which seemed to be absent in the world after the "end of history." This is why we read Weber's texts with such hope for a better understanding of contemporary reality. This is why we have been expecting so much from this issue of the Russian Sociological Review. To a certain extent, our concerns and hypothesis have been proven - we received many submissions related to the contemporary relevance of Max Weber's theories to the political realm of our time. We hope that the papers included will contribute to the reconsideration of Weber's legacy and to classical sociology overall. In what follows, we provide an overview of the issue by highlighting the main ideas of the papers.

The issue is composed of several papers and a couple of book reviews. Some papers can be classified under the topic of "Weber and Russia," while others are more theo- 
retically- and methodologically-oriented. The editors of the special issue decided not to group papers since many of them touch on interrelated aspects of the Weberian legacy.

The issue opens with a paper by William Outhwaite. In his contribution entitled "Max Weber's Conception of 'Rationalisation' and the 21st Century," he addresses the key concept of Weber's thought and explores the links between Weber's ideas and his own political orientation. As Outhwaite noted, Weber has been seen not only as a liberally-oriented scholar, but also as a nationalist. He shows that Weber's nationalism implied a certain tension between bureaucratic rationalization and politics. As described by Weber, the threats of the rationalization processes to the political leadership nowadays take a different form, i.e., a combination of nationalism with populist appeals. Outhwaite describes how Weber's framework can still be relevant to the recent European political crisis concerned with sovereignty (Brexit), and shows that his ideas are still fruitful.

Vadim Kvachev continues the discussion of Weberian notions in his review essay "From Weberian Bureaucracy to Networking Bureaucracy." He begins with the historical-sociological and theoretical analysis of the notion of bureaucracy, and places Weberian ideas in the context of post-modern philosophical thought of the second half of the 2oth century (Michel Foucault and Giorgio Agamben). The second part of his paper is dedicated to the outline of contemporary tendencies (the development of ICT, and increasing rationalization and deregulation) that enable the transformation of Weberian bureaucracy as an intellectual tool into a networking bureaucracy.

The contemporary political relevance of Weber's methodological ideas is the key focus of Konstantin Gaaze's contribution, "Max Weber's Theory of Causality: Examination on Resistance to Post-Truth." Particularly, he relates the model of adequate causation as developed by Weber and the notion of post-truth, which has become quite popular these days. This intriguing comparison of the two ideas, one from the beginning 2oth century while the other is from the 21st century, is carried out via the exploration of the theoretical context of Weber's studies (Gaaze provides an overview of von Kries' theory of objective possibility that was an important foundation for Weber's argument), and results in the critical examination of adequate and chance causation models.

The next paper continues the methodological discussion of Weber's legacy. This time, though, the contribution of "The Calling and Humility Scale: Extending the Weberian Approach to the Research of the Elective Affinity between Religion and the Economy" by Ivan Zabaev and Elena Prutskova is more concerned with the development of empirical tools in order to study the relations of economy and religion. As the authors suggest, calling is no longer the only ethics in economic and social relations, and there is a lack of reliable instruments to explore all the contemporary variety of ethical orientations as well. Zabaev and Prutskova present their considerations related to the construction of a scale to measure ethical orientations that will take into account the ethics of calling as well as humility.

A number of papers in the special issue are dedicated to Weber's writings on Russia. The first - "Max Weber on Russia: between Modern Freedom and Ethical Radicalism" by Camilla Emmenegger - examines Weber's oeuvre on Russian revolutions that 
is mostly neglected and considered as less important than his writings on methodology or religion. The author shows how Weber's writings on Russia, being very relevant and occasional responding to the historical events of his times, are full of theoretical and political philosophical reflections on the nature and genealogy of modern freedom. Weber connected the emergence of freedom to radical puritanism.

Andrey Teslya chose a different focus within the broad topic of "Weber and Russia." His contribution is a study of how Weber's famous Protestant Ethic was received in Russia. At the time of its publication in Germany, the book did not cause any significant intellectual debates in Russia. However, Teslya focuses on two Russian philosophers of the beginning of the 2oth century, Peter Struve and Sergei Bulgakov, who were the most attentive readers of Weber at that time. While Struve reflected on the nature of Christianity in the light of Weber's studies, Bulgakov attempted to apply Weber's general framework of the relation between religion and economy to the Russian context.

In his contribution of "Weber's and Sorokin's Analytical Treatment of the Russian Revolutions," Edward Ozhiganov compares two sociological views on the events of 19171918. In a critical way, Ozhiganov shows that both Weber and Sorokin failed to grasp the essence of the revolutionary events for various reasons. While Weber limited his analysis due to his concerns with the further participation of Russia in the Great War and did not follow his own research methodology, Sorokin constructed a positivistic framework that was not able to grasp the complexity of the events.

The next paper continues the exploration of the links between Weber's biography and his theoretical and political views. Nikolay Golovin argues that Weber's turn towards political essays during the Great War can be explained once his less-known letters are taken into account. For Golovin, Weber still followed his research ideals in these essays and letters; therefore, his political writings and essays can be seen as examples of applied historical sociology.

Another paper discusses Weber's thoughts on revolution. Timofey Dmitriev focuses on Weber's writings on the November revolution of 1918 in Germany. It is a review essay in which the author follows Weber's analysis of post-War times in Germany and shows its overall theoretical relevance. In this analysis, Weber once again addressed the issues of rationalization and bureaucratization and their threat to modern freedom. Dmitriev, along with Emmenegger, Kvachev, and other contributors, stresses the contemporary relevance of Weber's thought; it may seem that Weber's applied analysis may cause only historical interest but actually has many implications for today.

The last paper of the issue is a review by Mikhail Maslovskiy. Entitled "The Soviet Version of Modernity: Weberian and Post-Weberian Perspectives," it outlines a variety of approaches in historical sociology to Soviet society. He shows the limitations and controversies of these approaches once they are applied to the Soviet realm. Thus, as Soviet modernity was not a solid and homogenous entity, the approaches towards particular periods of its history should also differ and be more nuanced and empirically-oriented.

Two book reviews complete the special issue. Irina Trotsuk reviews Kieran Allen's Weber: Sociologist of the Empire in detail. In his book, Allen tries to go beyond the conven- 
tional view of Weber as a founding father of sociology and show how this view emerged due to the Americanization of Weber, and what ideological foundations lie behind the "true" Weber. Oleg Kildyushov contributed to the issue with the review of Max Weber und Siene Kreise: Essays, a collection of essays on Weber by the recognized German scholar Mario Rainer Lepsius, who is now famous for his work on the complete edition of Weber's works titled Max-Weber-Gesamtausgabe.

\title{
References
}

Adair-Toteff Ch. (2014) Max Weber: “A Source of Endless Fascination”. Sociology, vol. 48, no 1, pp. 186-191.

Alexander J. (1987) The Centrality of the Classics. Social Theory Today (eds. A. Giddens, J. Turner), Stanford: Stanford University Press, pp. 11-57.

Flyvbjerg B. (2001) Making Social Science Matter: Why Social Inquiry Fails and How it Can Succeed Again, Cambridge: Cambridge University Press.

Turner B. S., O’Neill J. (2001) Introduction: The Fragmentation of Sociology. Journal of Classical Sociology, vol. 1, no 1, pp. 5-12.

Münch R. (1982) Theorie des Handelns.: Zur Rekonstruktion der Beiträge von Talcott Parsons, Emile Durkheim und Max Weber, Frankfurt am Main: Suhrkamp.

Münch R. (2011 [1988]) Understanding Modernity: Toward a New Perspective Going beyond Durkheim and Weber, London: Routledge.

Münch R. (2016) The Global Division of Labour Development and Inequality in World Society, London: Palgrave Macmillan.

Simmel G. (1902) The Number of Members as Determining the Sociological Form of the Group, I. American Journal of Sociology, vol. 8, no 1, pp. 1-46.

Weber M. (2019) Economy and Society: A New Translation (trans. K. Tribe), Cambridge: Harvard University Press.

\section{Социология Макса Вебера в XXI веке: от рецепции к актуализации}

\author{
Александр Филиппов \\ Доктор социологических наук, профессор, руководитель Центра фундаментальной социологии \\ Национального исследовательского университета «Высшая школа экономики» \\ Адрес: ул. Мясницкая, д. 20, г. Москва, Российская Федерация 101000 \\ E-mail: filippovaf@gmail.com
}

\section{Наиль Фархатдинов}

Старший научный сотрудник Центра фундаментальной социологии Национального исследовательского университета «Высшая школа экономики»

Адрес: ул. Мясницкая, д. 20, г. Москва, Российская Федерация 101000

E-mail: nfarkhatdinov@hse.ru 